\title{
Understanding the Determinant of Income from Catfish Production in Imo State, Nigeria
}

\author{
Esiobu, Nnaemeka Success ${ }^{1}$ (ORCID iD; 0000-0002-9731-6663); \\ Osuji Uchenna Theresa ${ }^{2}$; Akande, Stella Ndidi²; Udunwa, Nkechi Bridget ${ }^{2}$; and Jonah, Marcylo Chukwu ${ }^{2}$ \\ ${ }^{1}$ Department of Agricultural Economics, Extension and Rural Development, \\ ${ }^{1}$ Imo State University, Owerri, Nigeria \\ ${ }^{2}$ Federal College of Land Resource Technology Owerri Imo State, Nigeria, \\ ${ }^{2}$ Agricultural Extension and Management
}

\begin{abstract}
Fish production is significant to Nigeria's aggregate economy. In Imo State in particular, it contributes to employment and income generation; food security; foreign exchange earnings and bridging protein demand-supply gap. Despite all these, empirical studies that logically, explain the determinant of income from catfish production are still relatively scanty. These creates a vacuum in research and knowledge thereby make it extremely difficult if not impossible for the government and other relevant stakeholders to know the method they can use in helping farmers realize huge income from catfish production as well as prospective farmers to venture into catfish farming. It was on this backdrop that the study was systematically undertaken in the area. Data were elicited from 90 catfish farmers' selected using multistage and purposive sampling procedure across Imo State, Nigeria. Data collected were analyzed using descriptive statistical tool, gross income and multiple regression analysis. Result show that the mean age was 45.00 years. Greater proportions $(71.11 \%)$ were male. Majority $(78.88 \%)$ were married with an average household size of 7 persons. The mean educational level and farming experience were 12 and 15.00 years respectively. Reasonable proportions $(68.89 \%)$ have no access to credit. Average annual farm income was $\$ 650,000.00$ (\$1,570.64). Majority (45.56\%) used concrete pond while approximately $47.78 \%$ of the farmers sourced their fingerling from commercials fish hatchery. Net farm income and return per capita invested were $\$ 3,050,714.69$ (\$7,371.65) and $\$ 15.41 \mathrm{k}$ respectively. The profitability index was $\$ 15.30$, which implies that for every naira earned as revenue from the catfish farming, about 15.30 kobo returned to farmer as net farm income. Estimated regression results shows that pond size $\left(\mathrm{X}_{1}\right)$; cost of fish feed $\left(\mathrm{X}_{2}\right)$; cost of labour $\left(\mathrm{X}_{3}\right)$; stocking rate $\left(\mathrm{X}_{6}\right)$; Educational Level $\left(\mathrm{X}_{9}\right)$; Farm Income $\left(\mathrm{X}_{10}\right)$ and Farming Experience $\left(\mathrm{X}_{11}\right)$ were the major determinant of income in catfish production. Findings provided evidence that catfish production is efficient and lucrative in the area. However, approximately $97.78 \%$ of the farmers complained of inadequate production capital. It was therefore recommended that farmers particularly on their own should judiciously pool productive resources together through strengthened and stable cooperative society group as this would enhance their profitability in catfish production in the area. Moreover, effective agricultural policies and programmes should focus on granting fish farmers improved access to farm credit as these would enable them increase their production frontier and realize huge profit overtime in the area.
\end{abstract}

Keywords: Catfish; Income, Profitability, Management System, Imo State, Nigeria

DOI: $10.7176 / \mathrm{JESD} / 13-1-03$

Publication date: January $31^{\text {st }} 2022$

\section{Introduction}

In Nigeria, agriculture provides between 80 to 90 percent of the country's food needs (National Bureau of Statistics (NBS), 2021). It, however, has diverse aspects and this includes fish farming which involves the rearing of fish for the purpose of consumption or sale. Fish is known to be the principal source of animal protein for over one billion people globally and provides many important nutritional and health benefits (Iruo et al., 2020). Fish has the highest level of easily metabolisable proteins; it is reputed for its high quality proteins, fats, vitamins, calcium, iron and essential amino acids. The per capital consumption of animal protein in the country has been put at $5 \mathrm{gm}$ per day (Federal Ministry of Agriculture and Rural Development, (FMARD), 2020), this is a far cry from the FAO's recommended level of $35 \mathrm{gm}$ per day (Food and Agricultural Organization (FAO), 2021). Catfish farming implies intervention in the rearing process of fish to enhance production such as regular stocking, feeding, and protection from predators amongst others. It is an important revenue earning enterprise especially at such a time, when the nation seeks to diversity its productive base from the monolithic nature or near total dependence on the oil sector to other sectors like agriculture. Fish farming also moves the nation towards achieving its goals of food security generates employment and saves foreign exchange revenue through import substitution of fish and fish product (Esiobu and Onubuogu, 2014). As the human population increases and consequent protein demand, the over-exploitation of the natural fish resources has made aquaculture a major option to combat protein malnutrition in the country (Etuk et al., 2021). The demand for fish protein is about 2.7million MT and only 800,000 MT is produced locally. It shows that there is still a short in supply of about 1.9million MT (Federal Department of 
Fisheries (FDF), 2020). Considering the fact that Nigeria has a large suitable land for fish culture, the potential of the aquaculture sector to meet the fish demand of the increasing population cannot be questioned and overemphasized. For the potential of this sector to be maximized, there must be a significant increase in the involvement of personnel in every area of the sector. For catfish, the absence of a solid estimate of the total economic cost and benefits are still scare. Even empirical evidence on the determinant of income from catfish production is still relatively shallow in the area. It was against these backdrops that the study was investigated

\section{METHODOLOGY}

The study was carried out in Imo State, Nigeria. Imo State is located in the eastern zone of Nigeria. The State lies between Latitudes $4^{\circ} 45^{\prime} \mathrm{N}$ and $7^{\circ} 15^{\prime} \mathrm{N}$ and Longitude $6^{\circ} 50^{\prime} \mathrm{E}$ and $7^{\circ} 25^{\prime} \mathrm{E}$ (Nigerian Meteorological Agency (NiMET), 2016). It is bounded on the east by Abia State, on the west by the River Niger and Delta State; and on the north by Anambra State, while Rivers State lies to the south (National Boundary Commission (NBC), 2020). Imo State covers an area of about $5,067.20 \mathrm{~km}^{2}$, with a population of 3,934,899 [(National Population Commission (NPC), 2006; National Bureau of Statistics (NBS), 2007)] and population density of about $725 \mathrm{~km}^{2}$ (Ministry of Land Survey and Urban Planning, 2015). The State has three Agricultural zones namely Okigwe, Orlu and Owerri Agricultural Zones. Structured questionnaire was used for data collection. The questionnaire was subjected to content and face validity through the help of experts. The population of the study consisted of all catfish farmers within Imo State. Multistage-sampling and purposive sampling procedures were used to select three agricultural zones in the State. From each sampled zone, three (3) Agricultural blocks was purposively selected based on the intensity of catfish farming. Then thirty (30) catfish farmers were selected from each of the three agricultural zones to give a total of ninety (90) catfish farmers for the study. Primary data were used for the study. The data were collected through the use of a set of structured questionnaire. This was supplemented with verbal interview in places where the respondents can neither read nor write. Descriptive statistics and inferential statistics were used in data analysis. The formular were stated as follows;

Gross Income;

$\mathrm{GI}=\mathrm{Q}$ X P

Where $\mathrm{Q}=$ Quantity of fish $(\mathrm{Kg})$

$\mathrm{P}=$ Unit price of fish

Net Income is specified as

$\mathrm{NI}=\mathrm{GI}-(\mathrm{TVC}+\mathrm{TFC})$

Where NI = Net Income $(\mathrm{N})$

$\mathrm{GI}=$ Gross Income

$\mathrm{TVC}=$ Total Variable Cost

TFC $=$ Total Fixed Cost

The multiple linear regression analysis was also stated as;

The implicit model is given as follows:

$\mathrm{Y}=\mathrm{f}\left(\mathrm{X}_{1}, \mathrm{X}_{2}, \mathrm{X}_{3}, \mathrm{X}_{4}, \mathrm{X}_{5} \mathrm{X}_{6}, \mathrm{X}_{7}, \mathrm{X}_{8}, \mathrm{X}_{9}, \mathrm{X}_{10}, \mathrm{X}_{11}\right) e i$

Where $\mathrm{Y}=$ Profitability $(\mathrm{N})$

$\mathrm{X}_{1}=$ Pond size (cubic metres)

$\mathrm{X}_{2}=$ Cost of Fish feed $(\mathrm{N})$

$\mathrm{X}_{3}=$ Cost of labour (Naira)

$\mathrm{X}_{4}=$ Cost of pond establishment (Naira)

$\mathrm{X}_{5}=$ Cost other implement (Naira)

$\mathrm{X}_{6}=$ Stocking Rate

$\mathrm{X}_{7}=$ Age (Years)

$\mathrm{X}_{8}=$ Sex (Male; $1 ;$ Female;0)

$\mathrm{X}_{9}=$ Educational level (years)

$\mathrm{X}_{10}=$ Farm Income (Naria)

$\mathrm{X}_{11}=$ Farming experience (Years)

$\mathrm{U}_{\mathrm{i}}=$ Error term 


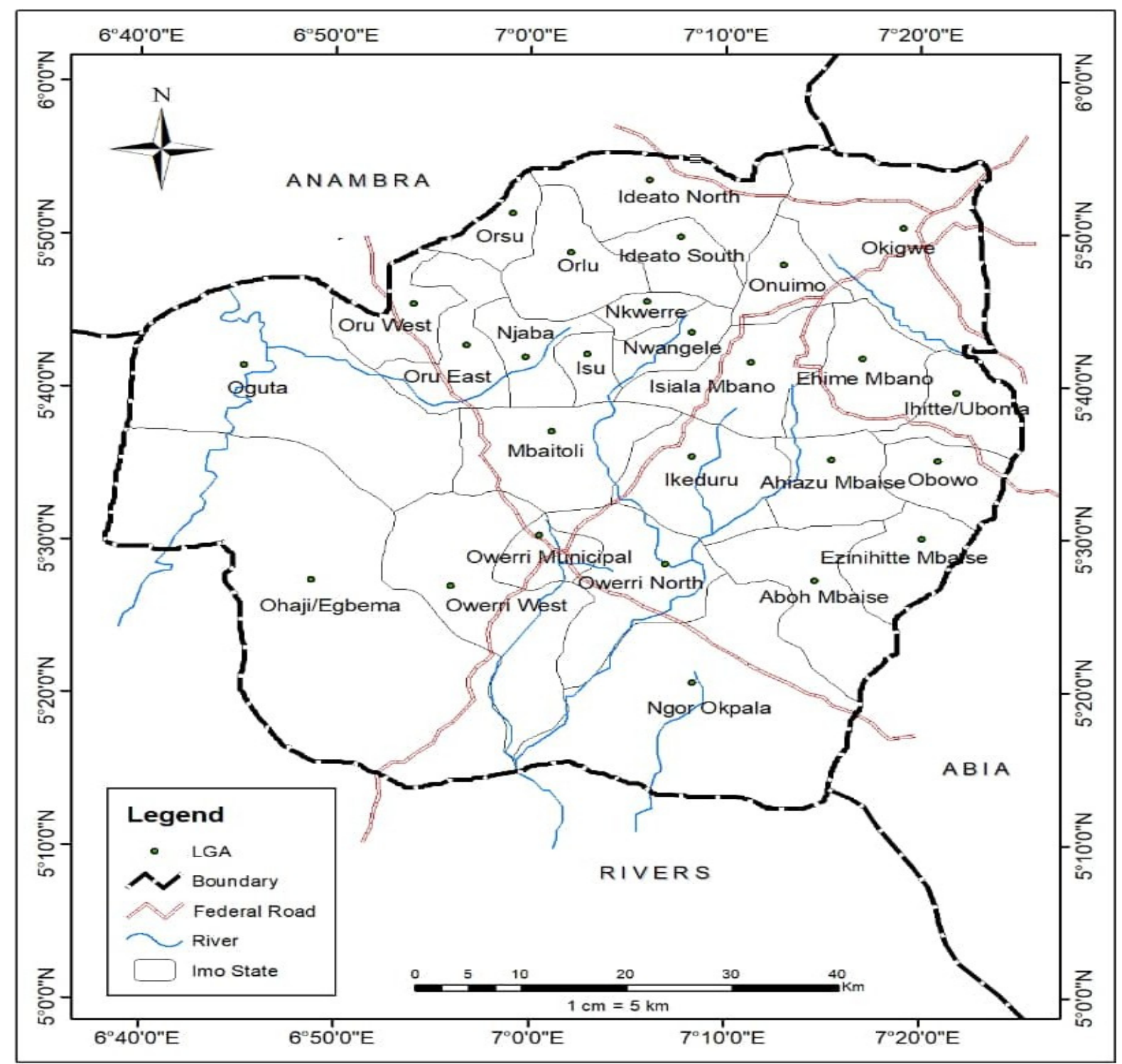

Figure 1: Map of Imo State Showing the 27 LGAs (Department of Geography, Imo State University, Owerri, Nigeria)

\section{RESULTS AND DISCUSSION}

\section{Socio-economic Characteristics of Catfish Farmers}

Table 1 revealed that majority (58.88\%) fell within the age range of $41-50$ years. The mean age was 45.00 years. This shows that farmers in the area are vibrant, young and still within the active age. Catfish farming is so strenuous. The implication is that younger farmers are more likely to withstand the stress and strain involved in catfish production in the area. Younger farmers are also more likely to make huge profit than their older counterpart. The result is in agreement with the study of Keremah and Esquire (2014) who reported that younger farmers normally dominate such strenuous ventures than older farmers are more likely to apply different method in increasing output and income in catfish farming. Table 1 also reveals that majority $(71.11 \%)$ of the farmers were males. The finding implies that both sex are involved in catfish farming but male are more in number in the area. The implication of males greater proportion may be that technical efficiency and productivity is expected to be higher because males have the tendency to be more labour efficient (Esiobu, 2019). 
Vol.13, No.1, 2022

TABLE 1: Socio-economic Characteristics of Catfish Farmers

\begin{tabular}{|c|c|c|c|}
\hline 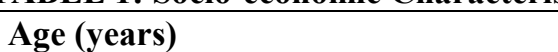 & Frequency & Percentage (\%) & Mean $(\mathbf{X})$ \\
\hline $30-40$ & 15 & 16.67 & \\
\hline $41-50$ & 53 & 58.88 & 45.00 years \\
\hline $51-60$ & 19 & 21.11 & \\
\hline $61-70$ & 3 & 3.33 & \\
\hline Total & 90 & 100.0 & \\
\hline Sex & Frequency & Percentage (\%) & \\
\hline Male & 73 & 71.11 & \\
\hline Female & 17 & 18.88 & \\
\hline Total & 90 & 100.0 & \\
\hline Educational Level & Frequency & Percentage (\%) & \\
\hline No formal education & 2 & 2.22 & \\
\hline Primary & 17 & 18.88 & \\
\hline Secondary & 61 & 67.78 & Secondary education \\
\hline Tertiary & 10 & 11.11 & \\
\hline Total & 90 & 100.00 & \\
\hline Marital Status & Frequency & Percentage (\%) & \\
\hline Married & 71 & 78.88 & \\
\hline Single & 11 & 12.22 & \\
\hline Widowed & 6 & 6.67 & \\
\hline Divorced & 2 & 2.22 & \\
\hline Total & 90 & 100.0 & \\
\hline Farming Experience (Years) & Frequency & Percentage (\%) & \\
\hline $01-10$ & 13 & 14.44 & \\
\hline $10-19$ & 68 & 75.56 & 15 years \\
\hline $20-30$ & 9 & 10.00 & \\
\hline Total & 90 & 100.00 & \\
\hline Household Size (Number of Persons) & Frequency & Percentage (\%) & \\
\hline $1-5$ & 13 & 14.44 & \\
\hline $6-10$ & 77 & 85.55 & 7 persons \\
\hline Total & 90 & 100.00 & \\
\hline Access to Credit & Frequency & Percentage (\%) & \\
\hline Access & 28 & 31.11 & \\
\hline No-access & 62 & 68.89 & \\
\hline Total & 90 & 100.00 & \\
\hline Access to Credit & Frequency & Percentage (\%) & \\
\hline Access & 307 & 75.80 & \\
\hline No-access & 98 & 24.20 & \\
\hline Total & 90 & 100.00 & \\
\hline Extension Contact & Frequency & Percentage (\%) & \\
\hline $1-2$ & 76 & 84.44 & \\
\hline $3-4$ & 14 & 15.56 & \\
\hline Total & 90 & 100.0 & \\
\hline Average Annual Farm Income (N) & Frequency & Percentage $(\%)$ & \\
\hline $100,001-300,000$ & 13 & 14.44 & \\
\hline $300,001-500,000$ & 19 & 21.11 & \\
\hline $500,001-700,000$ & 53 & 58.89 & $\$ 650,000.00(\$ 1,570.64)$ \\
\hline $700,001-900,000$ & 5 & 5.56 & \\
\hline Total & 90 & 100.00 & \\
\hline
\end{tabular}

\section{Source: Field Survey Data, 2021}

Entries in Table 1 also show that greater proportion (67.78\%) had secondary school education. The finding implies that approximately $97.78 \%$ of the farmers had formal education which is expected to increase their level of understanding and decision making on catfish production in the area. The result also support the finding Olalekan et al., (2014) who asserted that higher level of education determines the quality of skills of farmers and profitability of catfish fish production enterprise. Result in Table 1 shows that majority (84.44\%) were married. The finding implies that catfish farming is an enterprise of married individual who are expected to be responsible 
according to societal standard. This finding supports the result of Olawunmi et al., (2010) who reported that married farmers tend to have easy access to production variables such as land and large family size which are traditionally owned and provided by household heads (husbands) to compliment family labour to enhance production, reduce the cost of hired labour and resource use efficiency of the household farmers. Result of farming experience is shown in Table 1 and it shows that about $75.56 \%$ of the farmers had a farming experience ranging from 10-19 years. The mean year of experience in farming was 15.00 years. This suggests that the fish farmers had been engaged in catfish production for a relatively short period of time in the study area. In the same vein, this may be attributed to the fact that commercial catfish production is a relatively new idea in the study area. It also show that the farmers have had an experience about the fish farming which implies that they have knowledge of managing the enterprise for the purpose of maximizing production. This finding also supports Orgu et al., (2021) who reported that farmers with more experience would be more efficient, have better knowledge of climatic conditions to run a more efficient and profitable enterprise. Table 1 also shows that about $85.55 \%$ had a household size of 6-10. The mean household size was 7.0 persons. The study of Emokaro et al., (2012) opined that large household size ensures availability of labour and expansion of farm size. Table 1 outcome also reveals that greater proportion (68.89\%) do not have access to farm credit. The study of Ideba et al., (2013) asserted that access to credit affords farmers the opportunity of accessing farm credit for the purchase of farm inputs and increase production. Outcome in Table 1 also show that majority $(84.44 \%) \%$ ) of the farmers had no contact with extension agents. The implication of this finding is that since farmers in the study area are poorly visited by extension agents to ascertain their farming problems, know where they need assistance and pass across to them any new/improved technologies. In a similar way, Chukwu (2014) asserted that steady extension contact help to compliments farmers effort in their quest to increase yield, income and aggregate food production in Nigeria. Finally, Table 1 indicates that majority (58.89\%) had an average monthly farm income was between $\$ 500,001-\$ 700,000$. The mean annual farm income was $\$ 650,000.00$ (\$1,570.64) while the monthly farm income was estimated to be $¥ 54,166.66$ (130.89USD). The finding implies that the farmers have a relatively high farm income which is above the monthly national minimum wage in the area. The finding implies that farmers have a relatively high monthly farm income. The studies of Olaoye et al., (2013) asserted that farmers with higher farm income will perform better than those with low farm income since fish production requires reasonable among of fund.

\section{Type of Pond Used by Farmers}

The result of the farmers distribution based on type of pond used is presented in Figure 2. It shows that about $45.56 \%$ of the farmers used concrete pond in their catfish production. The high proportion observed in the use of concrete pond might be due to its convenience, ease in cleaning and management of the pond and in particular ease of harvesting and draining. It is commonly believed by the farmers to be advantageous in the area of high profitability, absence of weed growth or bank erosion, good control of diseases and predators inter alia. Concrete ponds are pond constructed using cement and concrete. It is the most expensive both in cost of construction and maintenance. The study of Dauda et al., (2014) opined that concrete ponds, if properly constructed, can last a lifetime. In addition, they can be constructed with vertical walls to increase the ratio of gallonage to surface area. However, the material for concrete is generally expensive and requires much skill to install. Similarly, the study is in line with the findings of Akhilomen et al., (2015) who reported that farmers use concrete pond in catfish production because of it high production ratio. More so, approximately, $24.44 \%, 17.78 \%, 10.00 \%$ and $2.22 \%$ of the farmers identified plastic pond, earthen pond, tarpaulin pond and case pond respectively as what they use in catfish production in the area. Simplicity and inexpensiveness of earthen pond in its construction could be the basic reasons for its preference. Earthen ponds are entirely constructed from soil materials. The study of Adeogun et al., (2007) reported that earthen ponds involves digging the soil usually clay (25.00\% clay) to a depth ranging from 0.5- $1.0 \mathrm{~m}$ at shallow end and 1.5- $2.0 \mathrm{~m}$ at the drain end to raise fish. Additionally, Nigerian farmers have limited land, therefore tank, tarpaulin, fish and case farming adapts well to their conditions than larger, more expensive earthen or concert ponds. It has also been noted that the quantity of fish harvested from such smaller production units is more easily marketed than harvests from large fish ponds (Igwe and Mgbaja, 2014). 


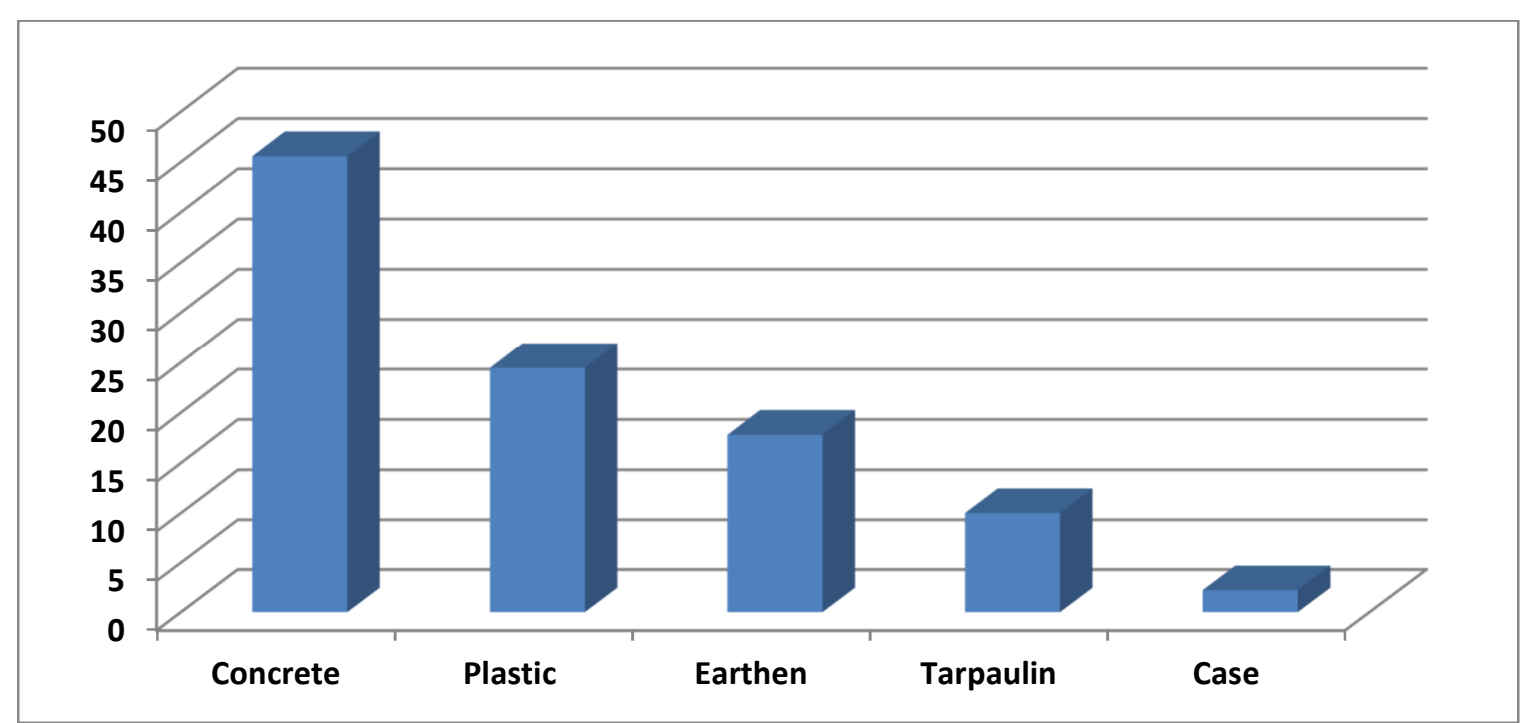

Figure 2: Type of Pond Used by Farmers; Source: Field Survey Data, 2021

\subsection{Source of Fingerlings of Farmers in Catfish Production}

Outcome of farmers distribution based on source of fingerlings is shown in table 2. It reveals that about $47.78 \%$ and $20.00 \%$ of the farmers identified commercials fish hatchery and Private/individual small scale farmers as their source of fingerlings used in fish production. The farmers reason for sourcing their fingerlings from commercials fish hatchery and private/individual small scale farmers could be that the source is trusted and reliable. The study of Aquaculture and Inland Fisheries Project (AIFP) (2012) asserted that farmers will only source for fingerlings from hatchery they can be able trust in term of healthy, early-maturity and disease-free breed. Approximately, $17.78 \%, 8.89 \%$ and $5.56 \%$ of the farmers sourced for their fingerlings from state government, federal fish hatchery and any available source. The low values recorded in Federal and State fish hatchery could be because of government poor support to her fishery ministry. During the fieldtrip, the study found out that most of State and Federal government staff owns a personally/commercial hatchery and also encourages fish farmers to buy from their hatchery than government owed.

Table 2: Source of Fingerlings of Farmers in Catfish Production

\begin{tabular}{llll}
\hline S/No & Source of Fingerlings & Frequency & Percentage (\%) \\
\hline 1 & Commercials Fish Hatchery & 43 & 47.78 \\
2 & Private/individual small scale farmers & 18 & 20.00 \\
3 & Federal Fish Hatchery & 8 & 8.89 \\
4 & State government & 16 & 17.78 \\
5 & Any available source & 5 & 5.56 \\
\hline & Total & $\mathbf{9 0}$ & $\mathbf{1 0 0 . 0}$ \\
\hline
\end{tabular}

Field Survey Data, 2021

\section{Costs, Return and Profitability of Catfish Production}

The result of the farmers distribution based on costs and return of catfish production is compiled in Table 3 . The result revealed that greater proportion (88.76\%) of the cost was recorded in the total variable cost. Similarly, about $26.34 \%$ of the variable cost was from cost of fingerlings, approximately $2.50 \%$ of the variable cost was recorded in labour while about $3.32 \%$ of the variable cost was recorded in miscellaneous expenses. Additionally, about $5.01 \%$, each of the total variable cost was utilized in water, vaccination, medication and storage. The highest contribution was in fish feed which contributed about $30.10 \%$ in the total variable cost. Moreover, several studies (Ugwumba and Chukwuji, 2010; Igwe and Mgbaja, 2014) on catfish production in Nigeria have confirmed that the cost of labour input is the most important of all cost components incurred in catfish production. The contribution of the fixed cost was relatively low compared to the variable costs incurred in production. The fixed cost contributed approximately $11.15 \%$ of the cost involved in catfish production in the area. The study of Crentsil and Inibehe, (2014) also confirmed that fixed cost is the least cost incurred in catfish production in Nigeria. The return on capital (ROC) invested was found to be N15.41. It could be inferred that for every naira invested, there is 15.41 kobo returns for the farmer in catfish production in the area. The result also revealed that the total revenue (TR), gross margin (GM) and net farm income (NFI) were $\mathrm{N} 3,250,000.00, \mathrm{~N} 3,072,971.00$ and $\mathrm{N} 3,050,714.69$ respectively. The finding also shows that net return on investment (NROI) (profitability index) was N15.30, which implies that for every naira earned as revenue from the catfish production enterprise 15.30 kobo returned to farmer 
as net farm income. In the same way, the finding shows that catfish production is a profitable enterprise and would yield more output/income when invested in a larger scale and efficiently managed. The result obtained confirmed the evidence of the finding of Olasunkanmi (2012) who revealed that catfish production is profitable and that farmers would realize good yield as well as income after sales when efficiently and effectively managed. These figure could yield more income if production scale is enhanced in the area and maybe beyond. The implication of the findings is that when efficiently, carefully, heavily invested and managed, catfish production is capable of producing good output/yield per hectare as well as reasonable net return over time to any agribusiness entrepreneur.

Table 3: Estimated Costs, Return and Profitability Analysis of Catfish Production/ Naira

\begin{tabular}{|c|c|c|c|c|c|}
\hline Items & $\begin{array}{l}\text { Average Cost } \\
\text { (N) }\end{array}$ & Quantity & Unit & $\begin{array}{l}\text { Total Value } \\
(\mathrm{PxQ})(\mathrm{N})\end{array}$ & $\begin{array}{l}\text { Percentage } \\
(\%)\end{array}$ \\
\hline \multicolumn{6}{|l|}{ A. Revenue } \\
\hline Catfish & 2500.00 & 1300 & $2 \mathrm{~kg}$ & $3,250,000.00$ & \\
\hline Total Revenue & --- & & --- & $3,250,000.00$ & \\
\hline \multicolumn{6}{|l|}{ B. Variable Cost } \\
\hline Fish feeds & 10,000 & 6 & Bags & $60,000.00$ & 30.10 \\
\hline Transportation & $2,000.00$ & 5.0 & $\mathrm{~km}$ & $10,000.00$ & 5.01 \\
\hline Fingering Stocking (kg) & 35.00 & 1500 & Fingerling & $52,500.00$ & 26.34 \\
\hline Labour & $1,000.00$ & 5.0 & Man hour & $5,000.00$ & 2.50 \\
\hline Water & $1,000.00$ & 10.0 & Litres & $10,000.00$ & 5.01 \\
\hline Medication & $2,000.00$ & 5.0 & Times & $10,000.00$ & 5.01 \\
\hline Vaccination & $2,000.00$ & 5.0 & Times & $10,000.00$ & 5.01 \\
\hline Storage & $1,000.00$ & 5 & Days & $10,000.00$ & 5.01 \\
\hline Petrol & 145.00 & 20 & & $2,900.00$ & 1.45 \\
\hline Miscellaneous cost & $6,629.00$ & --- & --- & $6,629.00$ & 3.32 \\
\hline $\begin{array}{l}\text { Total Variable Cost } \\
\text { C. Fixed Costs }\end{array}$ & & & & $177,029.00$ & 88.76 \\
\hline $\begin{array}{l}\text { Depreciation on Equipments } \\
\text { (Weighing scale, Bucket, } \\
\text { generator and Pumping Sumor) }\end{array}$ & $10,281.31$ & --- & --- & $10,281.31$ & 5.15 \\
\hline Depreciation on pond & $2,395.00$ & 5.00 & Size & $11,975.00$ & 6.00 \\
\hline B. Total Fixed Cost & & & & $22,256.31$ & 11.15 \\
\hline D. Total Cost (TFC+TVC) & & & & $199,285.31$ & 100.00 \\
\hline Net farm income $[\mathbf{A}-(\mathbf{B}+\mathbf{C})]$ & $3,050,714.69$ & ---- & ---- & $3,050,714.69$ & \\
\hline Gross Margin (NFI + TFC) & $3,072,971.00$ & & & & \\
\hline Return on Capital Invested & 15.41 & & & & \\
\hline Net Return on Investment & 15.30 & & & & \\
\hline
\end{tabular}

Source: Field Survey Data, 2021; Depreciation on equipment was calculated using the Straight Line Depreciation Method (SLDM)

\section{Influence of Farmers Socio-economic characteristic on Profitability of Catfish}

The result of the farmers distribution based on estimation of farmers socio-economic characteristic on profitability of catfish production in the study area is presented in table 4. A multiple regression analysis was estimated in four functional forms (linear, semi log, double $\log$, and exponential forms). Based on the statistical significance of the coefficients, goodness of fit and the economic theory that supports socio-economic model, the semi-log regression function was chosen as the lead equation. The semi-log regression function was chosen as the lead equation based on the value of $\mathrm{R}^{2}(0.781)$, F-Ratio value (12.830), conformity of the signs with a priori expectations of the model and has the highest number of significant explanatory variables. The coefficient of multiple determinations $\left(\mathrm{R}^{2}\right)$ was found to be $78.10 \%$ and was statistically significant at $1 \%$ level of probability. This implies that the farmers socio-economic characteristic on had a significant influence profitability of catfish production and that the regression model has a very high explanatory power. This is an indication that $78.10 \%$ of the variation in Profitability of Catfish production was explained by the explanatory variables while the remaining $21.90 \%$ was explained by the stochastic variables. The marginal effect is presented as follows:

Pond Size $\left(\mathbf{X}_{1}\right)$ : The coefficient of pond size was positive and also significant at $1 \%$ level of probability. It has a direct relationship with profitability of catfish production and implies an important determinant of for output in catfish production. This implies that the more the size of a fish pond, the higher the output/profit. Farmers how had large pond size had higher output/profit and income than their counterpart with smaller pond size. The result was in line with the finding of Asa and Valerie (2015) who asserted that increase in pond size will propel a significant increase in output/profit.

Cost of Fish Feed $\left(\mathbf{X}_{2}\right)$ : The result of fish feed was positively related to the output/profit from catfish 
production enterprise and statistically significant at $1 \%$ level of probability. This shows that the quantity of feed given to the fishes is an important productive input in catfish production and increases the output/profit of the enterprise. Farmers who have access and financial capacity to quality and quality fish feeds will realize huge output/profit than their counterpart who do not have and financial capacity to quality and quality fish feeds in the area. The study agrees with the finding of Nwosu and Onyeneke (2013) who opined that quality and quality fish feeds result to huge output for the farmer.

Cost of Labour $\left(\mathbf{X}_{3}\right)$ : The coefficient of cost of labour was positively related to the output/profit from catfish production enterprise and statistically significant at $1 \%$ level of probability. This shows that the access to labour is an important productive input in catfish production and increases the output/profit of the enterprise. Farmers who have access and financial capacity to labour will realize huge output/profit than their counterpart who do not have access to labour in the area. This finding supports the result of Olawunmi et al., (2010) who reported that married farmers tend to have easy access to production variables such as land and large family size which are traditionally owned and provided by household heads (husbands) to compliment family labour to enhance. This finding also supports the result Ajao (2012) who reported that large household size compliment labour to enhance production and reduce the cost of hired labour in catfish production.

Cost of Pond Establishment ( $\left.\mathbf{X}_{4}\right)$ : The coefficient of cost of pond establishment was significant at $1 \%$ level of probability and is positively signed. This implies that it has a direct relationship on the output/profit of fish production. The implication of the result is that fish farmers who began the enterprise with higher capital recorded higher output/profit than their counterpart who started with little capital.

The farmers who had a sizeable amount of start-up capital would purchase all the need for production in larger quality and made huge return than there counterpart who had little start-up capital. The finding shares view that the studies of Asa and Valerie (2015) who reported that start-up capital is a proxy for huge return/profit over time in catfish production.

Stocking Rate $\left(\mathbf{X}_{\mathbf{6}}\right)$ : The coefficient of stocking rate was highly significant at $1 \%$ level of probability and positively signed. This implies that it has a direct influence on the output/profit margin of catfish production. Farmers who stocked more fingerlings recorded higher output/profit than their counterparts who stocked less. The finding tallies with the studies of Keremah and Esquire (2014) who asserted that higher stocking capacity of famers gives higher output/profit of the farmer over time in catfish production.

Table 4: Influence of Farmers Socio-economic Characteristic on Profitability of Catfish

\begin{tabular}{lllll}
\hline Explanatory Variables & Linear & Semi-Log & Double-Log & Exponential \\
\hline Constant & 83.075 & 77.679 & 4.372 & 4.221 \\
& $(7.778)^{* * *}$ & $(3.176)^{* * *}$ & $(10.890)^{* * *}$ & $(31.626)^{* * *}$ \\
Pond Size $\left(\mathrm{X}_{1}\right)$ & 0.099 & 2.076 & 0.001 & $2.696 \mathrm{E}-030$ \\
& $(1.004)$ & $(3.758)^{* * *}$ & $(2.677)^{* * *}$ & $(3.873)^{* * *}$ \\
Cost of Fish Feed $\left(\mathrm{X}_{2}\right)$ & 0.341 & 0.397 & 0.007 & $3.855 \mathrm{E}-006$ \\
& $(2.517)$ & $(2.593)$ & $(3.635)$ & $(1.821)$ \\
Cost of Labour $\left(\mathrm{X}_{3}\right)$ & 0.330 & 3.588 & 0.057 & $2.213 \mathrm{E}-008$ \\
& $(2.289)^{* *}$ & $(3.113)^{* * *}$ & $(2.078)^{* *}$ & $(2.562)^{* * *}$ \\
Cost of Pond Establishment & 0.072 & 2.784 & 0.031 & $2.631 \mathrm{E}-016$ \\
(X) & $(2.605)^{* * *}$ & $(4.957)^{* * *}$ & $(3.003)^{* * *}$ & $(2.248)^{* *}$ \\
Cost Other Implement $\left(\mathrm{X}_{5}\right)$ & 0.496 & 0.345 & 0.069 & 0.007 \\
& $(0.216)$ & $(0.187)$ & $(2.147)^{* *}$ & $(0.328)$ \\
Stocking Rate $\left(\mathrm{X}_{6}\right)$ & 0.406 & 2.050 & 0.036 & $6.825 \mathrm{E}-006$ \\
& $(0.519)$ & $(3.390)^{* * *}$ & $(0.413)$ & $(1.518)^{*}$ \\
Age $\left(\mathrm{X}_{7}\right)$ & $1.305 \mathrm{E}-005$ & $9.903 \mathrm{E}-006$ & $1.674 \mathrm{E}-007$ & $2.397 \mathrm{E}-007$ \\
& $(2.554)^{* * *}$ & $(5.135)^{* * *}$ & $(2.169)^{* * *}$ & $(1.706)^{*}$ \\
Sex $\left(\mathrm{X}_{8}\right)$ & 0.936 & 4.634 & 0.076 & 2.027 \\
Educational Level $\left(\mathrm{X}_{9}\right)$ & $(0.735)$ & $(2.375)^{* *}$ & $(0.379)$ & $(3.824)^{* * *}$ \\
& 2.741 & 12.463 & 0.211 & 0.002 \\
Farm Income $\left(\mathrm{X}_{10}\right)$ & $(1.517)^{*}$ & $(5.607)^{* * *}$ & $(0.626)$ & $(0.914)$ \\
Farming Experience $\left(\mathrm{X}_{11}\right)$ & 0.251 & 8.952 & 0.152 & 0.004 \\
$\mathrm{R}^{2}$ & $(0.077)$ & $(3.578)^{* * *}$ & $(2.597)^{* * *}$ & $(0.313)$ \\
F-Ratio & 1.266 & 4.206 & 0.020 & $7.976 \mathrm{E}-006$ \\
Soure: Computer Print & $(3.469)^{* * *}$ & $(2.501)^{* * *}$ & $(0.391)$ & $(0.242)$ \\
& 66.10 & 78.10 & 55.20 & 60.50 \\
& $4.929 * * *$ & $12.830 * * *$ & $7.841 * * *$ & $8.829 * * *$ \\
\hline
\end{tabular}

Source: Computer Printout of SPSS (2021); values in Parenthesis are t-values *Statistically Significant at $10 \% ; * *$ Statistically Significant at $5 \% ; * * *$ Statistically Significant at $1 \%$

Age $\left(\mathbf{X}_{7}\right)$ : The coefficient of age was positive and significant at $1 \%$ level of probability implying that increases 
in the magnitude of age leads to a significant increases in profitability of catfish production. This implies that as fish farmers grows in age, experience increase and more profit will be realized in catfish production. The findings is in line with the study of Keremah and Esquire (2014) who argued that older farmers are not always enthusiastic about new farm technologies, especially if the benefits are not expected in the near future, but at the same time, farmers with advanced age are associated with more experience and thus likely to realize more profit in catfish production than their younger counterpart.

Sex $\left(\mathbf{X}_{8}\right)$ : The coefficient of sex was positive and significant at $1 \%$ level of probability implying that male farmers realized more profit than their female counterpart. This result is also justified by the assertion of Brummett et al., (2010) who opined that fishery activities are mostly dominated by men. However, aquaculture practices are not limited to a particular sex. Both male and female farmers are engaged in fish farming to increase fish production, improve food security, reduce hunger and also to increase their incomes. In the same vein, the result could also be attributed to the socio-cultural factor which gives males huge access to production variables such as like farmland, labour and other productive inputs more than female in the area.

Educational Level (X9): The coefficient of education was positive and significant at 1\% level of probability implying that increases in the magnitude of education leads to a significant increases in profitability of catfish production. The literacy level of these farmers is capable of promoting the sustainable fish production management practices in the area. Exposure to high level of education is positively and significantly related to profitability of catfish production. The result also support the findings Nwosu and Onyeneke (2013) and Olalekan et al., (2014) who asserted that higher level of education determines the quality of skills of farmers and profitability of catfish fish production enterprise.

Farm Income $\left(\mathbf{X}_{7}\right)$ : The coefficient of income was positive and significant at $1 \%$ level of probability implying that increases in the magnitude farm income leads to a significant increase in the profitability of catfish production in the study area. Farmers with higher farm income made more profit than their counterparts with smaller farm income. The finding implies that the farmers have a relatively high farm income which is above the monthly national minimum wage in the area. The finding implies that farmers have a relatively high monthly farm income. The studies of Olaoye et al., (2013) asserted that farmers with higher farm income will perform better than those with low farm income since fish production requires reasonable among of fund.

Farming Experience $\left(\mathbf{X}_{11}\right)$ : The coefficient of farming experience was positive and significant at $1 \%$ level of probability implying that increases in the magnitude of experience leads to a significant increases in catfish production in the study area. It is expected that higher year of farming experience will no doubt enhance their profit margin in catfish production in the area. The finding shares vein with the study of Obare et al., (2010) and Olasunkanmi (2012) who opined that year of farming experience has a positive and significant relationship with farmers' economic efficiency. This implies that the higher the level of experience of the farmer, the higher his cost efficiency level will be. This finding also supports Adebayo (2012) who reported that farmers with more experience would be more efficient, have better knowledge of climatic conditions, better knowledge of efficient allocation of resources and market situation and are thus, expected to run a more efficient and profitable enterprise. The F-ratio (12.830) which determines the overall significance of the regression model is highly significant at $1 \%$ level of probability implying that the regression model has very high explanatory power, hence the study concludes that farmers socio-economic characteristic have a significant influence on the profitability of catfish production in the study area.

\section{Constraints in Catfish Production}

The result of the farmers distribution based on constraints in pond fish production is shown in table 5. It revealed that larger proportion $(97.78 \%)$ of the farmers reported inadequate production capital. Fish farming is capital intensive and thus requires substantial volume of capital investment for reasonable profit to be made. This was indicated by Ugwumba and Chukwuji (2010) as one of the major problems facing catfish farmers in Anambra State, Nigeria. Adeogun et al. (2007) also reported lack of capital as one of the problems affecting aquaculture in Lagos State, Nigeria. In a similar way Nwosu and Onyeneke (2013) reported that poor capital is the bane of pond fish production in Imo State, Nigeria. The second serious constraint was the problem of high cost of feed as complained by $94.44 \%$ of the farmers. This is true as the study had earlier found that about $30.10 \%$ was incurred in feeds. More so, the scarcity of commercial pelleted and floating fish feed mills and problems associated with production and distribution of fish feeds could be the main reasons for the hike in feed prices. The studies of Keremah and Esquire (2014) opined that high cost feed as one of the problems of livestock production in Nigeria. These commercial fish feeds possess floating and high protein qualities and are therefore preferred by fish farmers (Ugwumba and Chukwuji, 2010). Furthermore, about $90.00 \%$ reported poor quality of fingerlings which was the third serious constraint. Farmers relied on the several hatchery sources which cannot be trusted. In the same vein, approximately $84.44 \%, 83.33 \%, 80.00 \%, 77.78 \%, 67.78 \%, 60.00 \%$ and $52.22 \%$ of the farmers complained of Long distance between farm and market, Poor access to suitable land/Site, Poor technical know-how, Poor quality of medication, Poor market outlet, Flooding and Theft respectively. Long distance to market makes most of the 
farmers sell their produce at farm gate hence having low profit margin. However, there is no doubt that these constraints are responsible for subsistence level of the farmers in the area. Fighting these problems will be vital in promoting not just subsistence production but commercial fish production in the area.

Table 5: Distribution of the Fish Farmers by Constraints in Fish Production

\begin{tabular}{llll}
\hline S/No & Constraints & Frequency & Percentage (\%) \\
\hline 1 & Inadequate production capital & 88 & 97.78 \\
2 & High cost of quality feeds & 85 & 94.44 \\
3 & Poor quality of fingerings & 81 & 90.00 \\
4 & Long distance between farm and market & 76 & 84.44 \\
5 & Poor access to suitable land/Site & 75 & 83.33 \\
6 & Poor technical know-how & 72 & 80.00 \\
7 & Poor quality of medication & 70 & 77.78 \\
8 & Poor market outlet & 61 & 67.78 \\
9 & Flooding & 54 & 60.00 \\
10 & Theft & 47 & 52.22 \\
\hline
\end{tabular}

*Multiple Responses were Recorded; Source: Field Survey Data, 2021

\section{CONCLUSION AND RECOMMENDATION}

Fish production is significant to Nigeria's economy in terms of provision of income, employment, foreign exchange earnings and bridging protein demand-supply gap. However conclusively, Net farm income and return

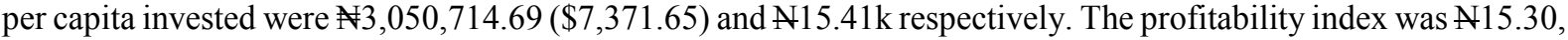
which implies that for every naira earned as revenue from the catfish farming, about 15.30kobo returned to farmer as net farm income. Estimated regression output shows that pond size $\left(\mathrm{X}_{1}\right)$; cost of fish feed $\left(\mathrm{X}_{2}\right)$; cost of labour $\left(\mathrm{X}_{3}\right)$; stocking rate $\left(\mathrm{X}_{6}\right)$; Educational Level $\left(\mathrm{X}_{9}\right)$; Farm Income $\left(\mathrm{X}_{10}\right)$ and Farming Experience $\left(\mathrm{X}_{11}\right)$ were the major determinant of income in the area. Findings provided evidence that catfish production is efficient and lucrative in the area. However, approximately $97.78 \%$ of the farmers complained of inadequate production capital.

\section{Recommendation}

i. It was therefore recommended that farmers particularly on their own should judiciously pool productive resources together through strengthened and stable cooperative society group as this would enhance their profitability in catfish production positively in the area.

ii. Moreover, effective agricultural policies and programmes should focus on granting fish farmers improved access to farm credit as these would enable them increase their production and realize huge profit positively in the area.

iii. It is also important the government at all level should identify genuine fish farmers and provide them with productive input as this would reduce the high cost of fish productive input in the area.

iv. Effective fishery policies should be directed to the establishment of commercial pelleted and floating fish feed mills, modern fish hatcheries, provision of credit facilities, provision of adequate infrastructural facilities and intensification of extension services.

v. Government should provide good feeder roads so that this fish produce can be transported easily and cheaply into areas where they are not produced.

vi. Farmers socio-economic characteristic was found to be one of the factors of profitability. Therefore, farmers education level, access to extension services and credit should be improved drastically.

\section{Acknowledgement}

We are very grateful to Prof. G.C. Onubuogu for reading the manuscript and checking its grammatical correctness and analysis. We are also grateful to our volunteer field enumerators who assisted in the data collection of this research. We say a very big thank you to the catfish farmers for their hospitality and taking their time in providing useful information that guided this research. Thanks to all those involved in data entry, data cleaning, data coding, and analysis. We cannot thank you all enough.

\section{Conflicts of interest}

The author declares no conflict of interest.

\section{Funding}

No external funding was received for this research.

\section{REFERENCES}

Adeogun, O. A., Ogunbadejo, H. K., Ayinla, O. A., Oresegun, A., Oguntade, O. R., Tanko, A., and Williams, S.B 
(2007). Urban Aquaculture: Producer Perceptions and Practices in Lagos State, Nigeria. Middle-East J. Sci. Res. 2 (1): 21-27

Ajao, A.O (2012). Determinants of Technical Efficiency Differentials among Concrete and Earthen Pond Operators in Oyo State-Nigeria; British Journal of Arts and Social Science; 4(2); 195-208

Akhilomen, L.O., Bivan, G.M., Rahman, S.A., and Sanni, S.A (2015). Economic Efficiency Analysis of Pineapple Production in Edo State, Nigeria: A Stochastic Frontier Production Approach; American Journal of Experimental Agriculture 5(3): 267-280

Aquaculture and Inland Fisheries Project (AIFP) (2012). Inventory of fish farms, lakes and feed Producers in Nigeria. National Special Programme for Food Security, Abuja, Nigeria. pp. 24.

Asa, U.A., and Valerie, A.S. (2015). Determinants of Catfish Production in Akwa Ibom State, Nigeria; Journal of Basic \& Applied Sciences, (11); 2; 11, 1-7

Baruwa, O. I., Tijani, A.A., and Adejobi, A.O. (2012). Profitability And Constraints To Fishery Enterprises: A Case Of Artisanal And Aquaculture Fisheries In Lagos; Nigerian Journal of Agriculture, Food and Environment. 8(1):52-58

Brummett, R. E., Youaleu, J., Tiani, L. N., Kenmegne, A. M. (2010). Women's traditional fishery and alternative aquatic resource livelihood strategies in the southern Cameroonian Rainforest. Fisheries Management and Ecology, 1(7), $221-230$.

Chukwu, A.O (2014). Farmers Perception Of Opinion Leaders In Agricultural Extension Delivery; Int'l Journal Of Agric. And Rural Dev.17 (3): 1967-1972

Crentsil, C. and Inibehe, G.K (2014). Production Function Analysis of Fish Production in Amansie-West District of Ghana, West Africa; American Journal of Experimental Agriculture 4(7): 817-835

Dauda, A.B., Oladele, A.H., and Elaigwu, A.M. (2014). Analysis of availability and consumption of cultured fish in some local government areas (LGAs) of Katsina State. Production Agriculture and Technology (PAT), 10(2): 110-118.

Emokaro, C.O., Ekunwe, P.A., and Achille, A. (2010). Profitability and viability of catfish farming in Kogi State, Nigeria". J. Agric. Biol. Sci. 6 (3):215-219.

Esiobu, N.S (2019). Relative Efficiencies Of Resource Use Among Cassava Farmers In Imo State, Nigeria; An M.Sc Thesis Submitted To The Department Of Agricultural Economics, Extension And Rural Development; Faculty Of Agriculture And Veterinary Medicine Imo State University, Owerri, Nigeria

Esiobu, N.S., and Onubuogu, G.C. (2014).Socio-economic Analysis of Frozen Fish Marketing in Owerri Municipal Council Area, Imo State, Nigeria: An Econometric Model Approach; Scholarly Journal of Agricultural Science, 4(8), 449-459

Etuk, E.A., Ogban, G. O. and Idiong, C. I. (2021). A comparative economic analysis of aquaculture production systems in Southern Agricultural Zone of Cross River State, Nigeria, African Journal of Agricultural Research, 17(1), 104-111

Federal Department of Fisheries (FDF) (2020). Fishing statistics, FDF, Abuja, Nigeria.

Federal Ministry of Agriculture and Rural Development (FMARD), (2020). Per capital consumption of animal protein in Nigeria, retrieved on $16^{\text {nd }}$ December, 2021 from https://fmard.gov.ng

Food and Agriculture Organization of the United Nations Organization (FAO). (2021). State of World Aquaculture. F.A.O Fisheries Technical Paper 500, Rome; 2021.

Ideba, E. E., Ibok, O.W., Antia-Obong, A., Okon, I.E., and Udoh, E.S. (2013). Economic Analysis of Fish Farming in Calabar, Cross River State, Nigeria; Greener Journal of Agricultural Sciences; 3(7), 542-549,

Igwe, K. C., and Mgbaja, J.U. (2014). Evaluation of Pond Fish Production in Umuahia South Local Government Area of Abia State, Nigeria; Global Journal of Science Frontier Research Agriculture and Veterinary; $14(1), 1-11$

Iruo, I.F., Onyeneke, R.U., Eze, C.C., Uwadoka, C., and Igberi, I.C. (2020). Economics of Smallholder Fish Farming to Poverty Alleviation in the Niger Delta Region of Nigeria, Turk. J. Fish.\& Aquat. Sci. 19(4), 313329

Keremah, I. R., and Esquire, J. (2014). Comparative Assessment of Growth Performance and Economics of Production of Clarias gariepinus Fingerlings in Ponds and Tanks; Greener Journal of Agricultural Sciences; 4 (2), 034-038

Ministry of Land Survey and Urban Planning (2015). Area of Imo State by LGA, Government Printer, Owerri. Imo State, Nigeria.

National Boundary Commission (NBC) of Nigeria (2020). Boundaries across South east, Nigeria, Retrieved on 10 April 2021 from https://nnn.ng/tag/national-boundary-commission-nbc/

National Bureau of Statistics (NBS) (2007). National Bureau of Statistics Official Gazette (FGP 71/52007/2,500(OL24): Legal Notice on Publication of the Details of the Breakdown of the National and State Provisional Totals, 2006 Census. Retrieved 28th March, 2021 from www.nigerianstat.gov.ng

National Bureau of Statistics (NBS) (2021). Agriculture Contribution in Nigeria; Data Monitor. Abuja, Nigeria: 
NBS. Retrieved on $24^{\text {th }}$ August 2021 from www.nbs.gov.ng

National Root Crops Research Institute, Umudike Meteorological Station, (NRCRIMS) (2020). Rainfall pattern across South east Nigeria, Retrieved 28th March, 2021 from NRCRIMS archive

Nigeria Population Commission (NPC) (2006). Nigeria Population Commission, Nigeria Federal Government Initiative of individual head count by gender. Spread, State by State, In :MOFINEWS; 6(3):Nigeria; Retrieved 28th March, 2021 from https://www.nationalpopulation.gov.ng/

Nigerian Meteorological Agency (NiMET) (2020). Drought, Rainfall and Flood Monitoring in South-East Bulletin 2020. Retrieved 28th March, 2021, from www.nimet.gov.ng

Nwosu, C.S., and Onyeneke, R.U. (2013). Effect of Productive Inputs of Pond Fish Production on the Output of Fish in Owerri Agricultural Zone of Imo State, Nigeria; Global Advanced Research Journal of Agricultural Science; 2(1), 023-028

Obare, G.A., Nyagaka, D.O., Nguyo, W. and Mwakubo, S.M. (2010). Are Kenyan Smallholders Allocatively Efficient? Evidence from Irish Potato Producers in Nyandarua North District". Journal of Development and Agricultural Economics, 2(3): 078-085

Olalekan, J.O., Adegbite, D.A., Oluwalana, E.O., Vaughan, I.O., Odebiyi, C.O., and Adediji, A.O. (2014). Comparative Evaluation Of Economic Benefits Of Earthen Fish Ponds And Concrete Tanks In Aquaculture Enterprises In Oyo State, Nigeria; Croatian Journal of Fisheries, 72(5), 107 - 117

Olaoye, O. J. (2010). Dynamics of the Adoption Process of Improved Fisheries Technologies in Lagos and Ogun States Nigeria. A Ph. D thesis in the Department of Aquaculture and Fisheries Management, University of Agriculture, Abeokuta, Ogun State, Nigeria. Pp. 337

Olaoye, O. J., Ashley-Dejo, S.S., Fakoya,E.O., Ikeweinwe, N.B., Ashaolu, F.O., and Adelaja, A.O. (2013). Assessment of Socio-Economic Analysis of Fish Farming in Oyo State, Nigeria; Global Journal of Science Frontier Research Agriculture and Veterinary; 13(9); 1-12

Olasunkanmi, J.B. (2012), Economic Analysis of Fish Farming in Osun State, South -Western Nigeria”, Proceedings of The International Institute of Fisheries Economics and Trade, Tanzania, $1-10$

Olawunmi, A. T., Dipeolu, A. O., and Bamiro, O. M. (2010): Economic Analysis of Homestead fish production in Ogun state, Nigeria. Journal of Human Ecology, 31(1), 13-17.

Orgu, K.C., Chukwu, A.O., Onubuogu, G.C., and Esiobu, NS (2021).Do Rural Livestock Farmers' have Knowledge of Organic Farming Practices? Lesson from Southeast, Nigeria, Book, UK, DOI: 10.5772/intechopen.99961

Ugwumba, C.O.A., and Chukwuji, C.O. (2010). The Economics of Catfish Production in Anambra state, Nigeria: A Profit Function Approach. J. Agric. and Soc. Sci. 6 (4): 105-109

Ugwumba, C.O.A., and Chukwuji, C.O. (2010). The Economics of Catfish Production in Anambra state, Nigeria: A Profit Function Approach. J. Agric. and Soc. Sci. 6 (4): 105-109 